\title{
Mandenkan
}

MANDENIKAN Bulletin semestriel d'études linguistiques mandé

59 | 2018

Numéro 59

\section{Moving ahead with replacive tone in Mande: A brief response to Konoshenko}

\section{Christopher R. Green}

\section{(2) OpenEdition}

1 Journals

\section{Electronic version}

URL: https://journals.openedition.org/mandenkan/1652

DOI: 10.4000/mandenkan.1652

ISSN: 2104-371X

\section{Publisher}

Llacan UMR 8135 CNRS/Inalco

\section{Electronic reference}

Christopher R. Green, "Moving ahead with replacive tone in Mande: A brief response to Konoshenko", Mandenkan [Online], 59 | 2018, Online since 20 July 2018, connection on 08 July 2021. URL: http:// journals.openedition.org/mandenkan/1652 ; DOl: https://doi.org/10.4000/mandenkan.1652

This text was automatically generated on 8 July 2021.

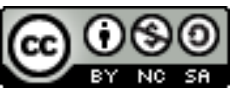

Les contenus de Mandenkan sont mis à disposition selon les termes de la Licence Creative Commons Attribution - Pas d'Utilisation Commerciale - Partage dans les Mêmes Conditions 4.0 International. 


\title{
Moving ahead with replacive tone in Mande: A brief response to Konoshenko
}

\author{
Christopher R. Green
}

\section{Introduction}

1 Stemming from my recent survey (Green 2018) upon which this discussion is based, it is now undoubtedly a fact that REPLACIVE TONE is a robust structural characteristic witnessed across most Mande languages. Up until this survey, there have been only two known attempts made at uncovering the extent to which replacive tonal phenomena are distributed across the Mande family, namely Dwyer (1973) and deZeeuw (1979). It has been more common, at least in contemporary studies of Mande tonology, for authors to concentrate on describing and analyzing replacive tonal patterns in particular languages without probing further either i) the distribution of surface patterns throughout in the family; or ii) the mechanisms (whether diachronic or synchronic or both) that underlie the patterns. This is arguably the case in my own work on Bambara (Green 2013) and Susu (Green, Anderson \& Obeng 2013) and Konoshenko's work on varieties of Kpelle (Konoshenko 2008; Konoshenko 2014) and Kono (Konoshenko 2017). It was with this concern in mind that the survey under discussion was undertaken, which far surpasses the coverage of Dwyer's five-language and deZeeuw's eight-language surveys by exploring replacive tonal data from nearly forty language varieties.

2 Despite the relative breadth of this survey, the work had two humble goals: i) describe and offer generalizations concerning the major SURFACE tonal patterns in Western Mande that have been or could be reasonably attributed to replacive tone; and ii) consider the ways in which these outcomes relate to a fairly recent classification schema for Mande proposed by Vydrin $(2009 ; 2016)$. The survey did not pretend to be 
exhaustive nor did it aim to make broader claims about the diachronic development of replacive tone in Mande.

3 As Konoshenko herself points out, the survey highlights the fact that for many of the languages surveyed, data are insufficient to yet subject them to a broader analysis, and for others, relevant data remain unavailable altogether, thereby precluding a truly global survey of replacive tone across the family. Konoshenko's critique of my survey, however, provides an excellent case in point in which the utility and necessity of such survey work is beneficial to the broader theoretical and typological enterprise. Such surveys can be foundational for research programs that aim to address larger lines of inquiry in that they compile and attempt to organize data from disparate sources that often adopt different descriptive and theoretical frameworks. Konoshenko, even in presenting a different viewpoint on the compiled data, highlights the fact that the survey reveals previously undiscussed idiosyncrasies in the behavior of certain languages that either cannot straightforwardly be accounted for in her nor my approaches.

Konoshenko presents two main critiques of my survey. The first of these is that a stark enough contrast is not drawn between the NATURE of the neutralized tonal outcomes in a W2; W1 and W2 refer to the first and second (or better yet, last) word in certain constructions that are typically implicated in Mande replacive tonal phenomena, and most often in noun phrases and compounds. Konoshenko argues that beyond the surface replacive tone patterns, a distinction should be highlighted between default tone assignment (these generally correspond to my Type 1 languages) vs. grammatical tone assignment (these generally correspond to my Type 2 languages). In addition, Konoshenko maintains a further distinction between High tone spreading from a W1 to a W2; in instances of replacive tone in Mande, such spreading is found only in what I have called Type 2 languages. A second critique is that the omission of Southern Mande languages from the survey introduces a gap that is key to understanding the broader scope of replacive tonal phenomena in the family. In the remainder of this brief paper, I respond to these critiques and then offer some possibilities for fruitful next steps that I believe will allow us to continue to move ahead in our inquiry into replacive tone in Mande.

\section{Rethinking the morphosyntactic $\mathrm{W} 2$ rule and tonal features}

Both my and Konoshenko's viewpoints on Mande replacive tone share a great deal of similarities and indeed support the same general classificatory distinction between languages. The approaches differ in some instances in terminology used and in at least one key analytical assumption asserted by Konoshenko that I do not expressly state concerning so-called Type 2 languages. Konoshenko argues that I fail to explicate that the $\mathrm{H}$ spreading rule between $\mathrm{W} 1$ and $\mathrm{W} 2$ in Type 2 languages is a general morphophonological or phonological rule that is not unique to compounding or to replacive tonal phenomena more broadly in Mande. Konoshenko variously uses both of the aforementioned terms to describe this Type of rule, so I am not clear whether she considers there to be a difference between the two and what this might entail for one set of analytical choices vs. another. Konoshenko indeed provides clear examples from her work on Guinean Kpelle (Konoshenko 2014, but also some of her unpublished field 
notes) in which $\mathrm{H}$ spreading is extensible to verb phrases and other nominal constructions that do not necessarily involve compounding. The difficulty with this critique, however, is that Konoshenko assumes an analysis on my behalf based on the description of the surface tonal patterns that she reports; nowhere do I assert that $\mathrm{H}$ spreading is unique to the replacive tonal phenomena under consideration.

This (MORPHO)PHONOLOGICAL rule is distinguished from the MORPHOSYNTACTIC or MORPHOLOGICAL nature of W2 grammatical \{L\} assignment (or lowering) which is clearly an indicator of the compounded relationship of two elements. Again, Konoshenko uses both terms, with the latter presumably being in the spirit of recent work by Palancar (2016), but it is unclear what distinction she assumes between these two types of rules. In Soso-Southwestern and Southern Mande, W2s are assigned a morphosyntactic grammatical tone or the tone is lowered, after which (morpho)phonological $\mathrm{H}$ tone spreading from W1 to W2 occurs, at least in most instances in Soso-Southwestern Mande.

7 W2 grammatical tone assignment, and replacive tone in Mande more broadly, are undoubtedly MORPHOSYNTACTIC in nature. As mentioned just above, however, Konoshenko's typology of Mande replacive tone maintains a distinction between W2 neutralization via default tone assignment in Central Mande vs. W2 neutralization via morphosyntactic lowering in Soso-Southwestern and Southern Mande. She appears to argue that the Central Mande phenomenon is expressly phonological in nature because it involves the assignment of a default tone that is supplied by the phonology.

8 In my view, it is at this point that Konoshenko's analysis falls short. Rather than maintaining a stark contrast between the "default" W2 and "grammatical tone/ lowering" W2 outcomes in the languages under consideration, as implied by Konoshenko, I would like to suggest an alternative in which we re-envision the so-called 'default' W2 neutralization patterns in Central Mande as also being morphosyntactic in nature. The viewpoint I put forward below would support the standing perspective that Proto-Mande replacive tone involved a Low W2 (Vydrin 2017) and would also bolster the diachronic claims that Konoshenko advances in her own analysis. Under this view, I envision there to be three slightly different W2 outcomes that arise in Mande that can be generated by the same morphosyntactic rule: assign a grammatical tone to W2. However, the differing surface realizations arising from this rule can be attributed to the particular tonal features associated with the assigned grammatical tone alongside language-specific phonological properties and their downstream application.

9 First, assuming that the grammatical tone marking W2 in Proto-Mande was $\{L\}$, Soso-Southwestern and some Southern Mande languages generally maintain this tone, though it may be subsequently obscured by innovated morphophonological $\mathrm{H}$ spreading between $\mathrm{W} 1$ and $\mathrm{W} 2$ or analogous raising/settling rules. Second, as Konoshenko has highlighted in her critique, some Southern Mande languages either maintain $\{L\}$ or instead witness innovative W2 lowering, sometimes to \{extra-L\}. One could propose that this arises via the loss or change of some (but not all) tonal features associated with the original grammatical tone. Lastly, one could view Central Mande languages as having W2 marked by a grammatical tone, though one that is synchronically underspecified for any particular tonal features; these tonal features are then filled in "by default". Viewed in this way, the mechanism for Central Mande replacive tone is not kept separate from those clearly exhibiting a specific grammatical 
tone. Rather, these languages have a featurally-underspecified, morphosyntactic grammatical tone assigned, with the surface realization of this tone is left to the phonology. The perspective proposed here differs from Konoshenko's in subtle ways in its conception, but in my view, it connects and unifies standing diachronic and synchronic perspectives on Mande replacive tone and importantly merges the strengths of both my and Konoshenko's offerings. While my survey aimed to provide a typology of surface tonal patterns, and Konoshenko's critique reconfigured the typology based on a two-way distinction predicated on the "nature" of the neutralized W2, what I have offered here perhaps moves us ahead by another step by admitting a richer interplay between syntax, morphology, and phonology in deriving replacive tonal patterns, rather than trying to hold them separate from one another. As Konoshenko suggests, the substantiation of these analyses will likely have to await further, more detailed work on other less well-described languages in the family.

\section{Next steps ahead and concluding thoughts}

current discussion pertaining to the typology of replacive tone patterns in Mande languages began with a survey of the surface patterns observed and has now shifted in focus to the NATURE (to use Konoshenko's term) of the neutralized W2 melody. I believe, however, that establishing a mechanism to account for the outcomes of the morphosyntactic W2 rule is just the next step along a longer path of understanding Mande replacive tone in its entirety. Two additional lines of inquiry immediately come to mind, only one of which has begun to be explored in detail, that may lead us even further down this path.

11 First, there is an outstanding question as to types of constructions in a given language that exhibit replacive tone and the mechanisms (be they phonological, morphological, syntactic, etc.) that dictate them. My survey focused primarily on replacive tone in nominal constructions like compounds, but there is ample evidence that replacive tonal phenomena are found in associative and possessive constructions, between a noun and its governing postposition, as well as between a verb and its object. Indeed, Konoshenko provides examples from Guinean Kpelle in her critique that illustrate that replacive tonal patterns involving object-verb and noun-of-noun sequences behave identically; "tonal compounding" between an object and verb has also been discussed in recent work by McPherson (2017) on Seenku (a language of the underdescribed Samogho group of Mande). Several other types of "compact" constructions in Bambara are also discussed in Dumestre (2003). However, we do not know the extent to which these patterns are found in this wider variety of contexts throughout the family. Work by Creissels $(2013 ; 2016)$ also discusses so-called PARTIAL vs. COMPLETE replacive tone patterns, which are sometimes both represented in the same language yet have very distinct tonal outcomes. But again, it is yet unclear how widely spread PARTIAL replacive tone is distributed across the family.

12 A second area of inquiry concerns the role played by prosodic structure in the outcomes of replacive tone phenomena. While the first direction for future work that I suggested just above involves the intersections of phonology, morphology, and syntax (and perhaps other components), the role of prosodic structure in driving the outcomes of replacive tone is more clearly morphophonological in nature. Green (2013) discussed many "tonally compact" constructions in Bambara in reference to the language's 
prosodic word domain and proposed that the presence of "non-tonally compact" constructions in Bambara correlates with headedness and the mechanism of word formation, namely whether word formation involves rightward or leftward adjunction to the prosodic word domain. These details have yet to be explored in a wider variety of languages.

It may prove to be that prosodic structure also has a role to play in replacive tonal phenomena and more specifically in the surface distribution of the constituent tones of the W1 tonal melody upon compounding or some related construction. My survey illustrates the well-established fact that the W1 tonal melody is maintained to some degree in most instances of Mande replacive tone. Sometimes, only the initial tone of the W1 lexical melody is maintained like in Niokolo Maninkakan, with other tones of the melody being neutralized (1). In other languages, like Vai, the W1 tonal melody is more faithfully maintained (2).

(1) Niokolo Maninkakan (Creissels 2013)

- a. /tíbààbù/ 'European' + /músù/ 'woman' $\rightarrow$ [tíbààbù\#mùsù] 'European woman'

•b. /fùlà/ 'Fulbe' + /músù/ 'woman' $\rightarrow$ [fùlà\#mùsù] 'Fulbe woman'

•c. /bàránsàn/ 'tree species' + /jámbà/ 'leaf' $\rightarrow$ [bàrànsàñyjàmbà] 'leaf of baránsay'

• d. /wóròykòféndàà/ 'snail' + /nòò/ 'trail' $\rightarrow$ [wóròykòfèndàà\#nòò] 'snail trail'

(2) Vai (Welmers 1976)

- a. /jí/ 'water' + /sóó/ 'hole' $\rightarrow$ [jí-sòò] 'water hole, well'

•b. /wúnú/ 'mortar' + /kǒy/ 'stick' $\rightarrow$ [wúnú-kòy] 'pestle'

•c. /kávù/ 'rattan' + /jàndá/ 'thatch' $\rightarrow$ [kávù-jàndà] kávù 'thatch'

•d. /bâ/ 'mother' + /léy/ 'child' $\rightarrow$ [bâ-lèn] 'maternal aunt'

•e. /bò’ò/ 'cultivated greens' + /kúú/ 'fenced enclosure' $\rightarrow$ [bò'ò-kùù] 'garden'

•f. /jàmbá/ 'leaf' + /mכ̌/ 'person' $\rightarrow$ [jàmbà-móò] 'herbalist'

Moving beyond these two outcomes, the compiled Mande data reveal another interesting characteristic that at least preliminarily appears to unify many of the languages surveyed. That is, in Mande replacive tone, the lexical tonal melody of the W1 itself often comes to be represented (i.e., distributed) across the composite W1+W2 construction. The distribution of the constituent tones of the melody, however, appears to be dictated by language-specific phonological characteristics. Here I offer just a brief and, once again, preliminary illustration of relevant outcomes in select languages that speak to this observation.

For example, data from Bambara (3) reveals that a lexical /LH/ W1 melody is distributed across a compound regardless of the lexical melody of a following W2; the surface melody of $\mathrm{W} 1$ is $[\mathrm{L}]$ and $\mathrm{W} 2$ is [H]. Recall that Bambara is a "default W2" (Konoshenko) or "Type 1" (Green) language for which I suggested above one could assign a W2 $\{\varnothing\}$ grammatical tone. I adopt Konoshenko's suggestion of indicating the lexical melody with slash brackets, a grammatical tone with curly brackets, and the surface form with square brackets. The lexical W1 melody is mapped across W1+W2 such that one tone is assigned to each successive PROSODIC WORD.

(3) Bambara (Green 2013)

•/jàrá/ + /wòló/ $\rightarrow$ /jàrá/ + \{wolo\} $\rightarrow$ [jàrà\#wóló] 'lion skin’

A W1 melody in a language like Mende is distributed in a slightly different way across a compound. Recall that Mende fits under the heading of W2 $\{\mathrm{L}\}$ languages with subsequent H spreading in Konoshenko's analysis. The example in (4) shows that the 
tones of a /LLH/ lexical W1 melody are distributed across the larger construction such that one tone is associated with each successive TONE BEARING UNIT on the surface. The surface W1 melody is [LL] and that of the W2 is [HL], with the final low being due to the W2 $\{\mathrm{L}\}$.

(4) Mende (Spears 1967)

•/ndòmă/ + /nìnă/ $\rightarrow$ /ndòmă/ + \{nìnà $\rightarrow$ [ndòmà\#nninà] 'new shirt'

Susu has a more complex inventory of tonal melodies, but even in this language, the same general principle holds. The example in (5) shows that a /LLHL/ W1 comes to be distributed across a composite $\mathrm{W} 1+\mathrm{W} 2$ construction, but here, the tones of the W1 melody are distributed FоOт-BY-FоOT. The W1 surface melody is [LLHH] and the W2 is [L]. Of course, Susu is known to be a W2 $\{\mathrm{L}\}$ language, so the status of the surface W2 tone here is ambiguous.

(5) Susu (Green, Anderson \& Obeng 2013)

•/kòòkóó/ + /xórì/ $\rightarrow /$ kòòkóò/ + \{xòrì $\rightarrow$ [kòòkóó\#xòri] 'cocoa nut'

A language like Dantila Maningaxay is perhaps a somewhat divergent case (keeping in mind that the source of these data are unpublished) but one that nonetheless follows from the principles outlined thus far. The example in (6) shows that a lexical /LH/ W1 melody is distributed across a compound in such a way that the entire W1 melody comes to be associated in its ENTIRETY on each PROSODIC WORD. The final $\mathrm{L}$ tone here is due to the definite marker.

(6) Dantila Maningaxay (Doucouré \& Patin 2015)

-/tibá:bú/ + /mùsú/ $\rightarrow$ /tìbá:bú/ + \{musu\} $\rightarrow$ [tìbá:bú\#mùsô] 'European woman'

Of course, these are only a few examples, but in each of them the W1 melody comes to be distributed across the larger $\mathrm{W} 1+\mathrm{W} 2$ construction, though the prosodic unit by which the W1 tones are distributed (whether individually or as a melody) differs between languages. These outcomes are clearly morphophonological in nature and beg the question as to whether there is a replacive tone CONSPIRACY of sorts that has emerged in these languages, in the spirit of Kisseberth (1970), that is mediated by prosodic structure.

In this brief response to Konoshenko's critique, I have endeavored to accomplish three things. First, I aimed to clarify the scope and claims of the survey upon which this discussion is based. The survey, based on surface tonal melodies attributed to Western Mande replacive tone, made no explicit claim that $\mathrm{W} 1$ to $\mathrm{W} 2 \mathrm{H}$ tone spreading was unique to compounding. Secondly, stemming from Konoshenko's discussion of morphosyntactic vs. morphophonological rules, I have moved a step beyond her proposal by suggesting that the replacive tone outcomes witnessed in Central Mande perhaps share even more similarities to those in Soso-Southwestern and Southern Mande. More specifically, I suggested that Central Mande W2s might be assigned a $\{\varnothing\}$ grammatical tone analogous to other languages, after which default tonal features are assigned by the phonology. This unifies the "default W2" vs. "grammatical tone W2" dichotomy maintained in Konoshenko's analysis. Finally, I have attempted to outline two lines of inquiry that scholars might explore moving forward that may further help us to solidify our understanding of replacive tone in Mande, including downstream tonal processes and the structures mediating their specific outcomes. 


\section{BIBLIOGRAPHY}

\section{References}

Creissels, Denis. 2013. Le maninka du Niokolo (Sénégal oriental): esquisse phonologique et morphosyntaxique, liste lexicale, textes glossés. Mandenkan 49. 1-218.

Creissels, Denis. 2016. Phonologie segmentale et tonale du soninké (parler du Kingi). Mandenkan 55. 3-174.

deZeeuw, Peter Howard. 1979. Western Mande compound tone rules. Michigan State University MA thesis.

Doucouré, Salouma \& Cédric Patin. 2015. De la compacité tonale en mànìngàxáy du Dantila. Dakar.

Dumestre, Gerard. 2003. Grammaire fondamentale du bambara. Paris: Karthala.

Dwyer, David. 1973. The comparative tonology of Southwestern Mande nominals. Michigan State University PhD dissertation.

Green, Christopher R. 2013. Formalizing the prosodic word domain in Bambara tonology. Journal of West African Languages 40(1). 3-20.

Green, Christopher R. 2018. A survey of word-level replacive tonal patterns in Western Mande. Mandenkan 59. 67-108.

Green, Christopher R., Jonathan Anderson C. \& Samuel G. Obeng. 2013. Interacting tonal processes in Susu. Mandenkan 50. 61-84.

Kisseberth, Charles W. 1970. On the functional unity of phonological rules. Linguistic Inquiry 1(3). 291-306.

Konoshenko, Maria. 2008. Tonal systems in three dialects of the Kpelle language. Mandenkan 44. 21-42.

Konoshenko, Maria. 2014. The syntax of tone in Guinean Kpelle. Proceedings of BLS 40. 233-252.

Konoshenko, Maria. 2017. Field notes on Kono, a Southwestern Mande lect of Forest Guinea.

Mandenkan 57. 77-107.

McPherson, Laura. 2017. On (ir)realis in Seenku (Mande, Burkina Faso). In Jason Kandybowicz \& Harold Torrence (eds.), Africa's endangered languages: Documentary and theoretical approaches. New York: Oxford University Press.

Palancar, Enrique. 2016. A typology of tone and inflection. Tone and inflection: New facts and new perspectives 296. 109-140.

Spears, Richard A. 1967. Basic course in Mende. Evanston, IL: Northwestern University.

Vydrin, Valentin. 2009. On the problem of the Proto-Mande homeland. Journal of language relationship 1. 107-142.

Vydrin, Valentin. 2016. Toward a Proto-Mande reconstruction and an etymological dictionary. Faits de Langues 47. 109-123. 
Vydrin, Valentin. 2017. Mande jazyki (мАндЕ языки) [The Mande languages]. In Valentin Vydrine, Yulia Mazurova, Anderj Kibrik \& Elena Markus (eds.), Jazyki mira: Jazyki mande (языки миРА: Языки МАндЕ) [Languages of the world: Mande languages], 16-45. St. Petersburg: Nestor-Historia.

Welmers, William E. 1976. A grammar of Vai. Berkeley, CA: University of California.

\section{AUTHOR}

\section{CHRISTOPHER R. GREEN}

Syracuse University

cgreen10@syr.edu

Introduction 